increase in enzyme content dropped gradually and nearly ceased when the tuber attained the weight of about $100 \mathrm{~g}$.

It became probable that the increase in enzyme activity might be attributed chiefly to that in the "cortex with buds".

Sincere appreciation is expressed to Prof. T. Miwa, of the Tokyo University of Education, for his valuable advice and criticism during the course of this investigation and in preparation of this manuscript.

\title{
Literature
}

1) Allen, R. J. L., Biochem. J. 34:858 (1940). 2) Green, D. E. and Stumpf, P. K., J. Biol. Chem. $142: 355$ (1942). 3) Hanes, O. S., Proc. Roy. Soc. B 129: $174(1940)$. 4) Hidy, D. H. and Day, H. G., J. Biol. Chem. 160: 273 (1945). 5) Hori, S., Bot. Mag. Tokyo. 67 : 789-790 (1954). 6) Nakamura, M., Yamazaki, K. and Maruo, B., Jour. Agri. Soc. Jap. 24: 268 (1951). 7) Sumner, J. B. and Somers, G. F., Chemistry and Methods of Enzymes. 3rd ed. (1953). 8) Tagawa, T. and Okazawa, Y., Proc. Crop Sci. Soc. Jap. 23: 1 (1954).

\section{Seed Formation of Ellisiophyllum pinnatum var. reptans.**}

$$
\text { by Takasi YAMAZAKI* }
$$

山崎 敬*: キクガラクサの種子形成

Received January 30, 1957

Material and methods: The process of the seed formation was studied in Ellisiophyllum pinnatum Makino var. reptans (Maxim.) Yamazaki of Scrophulariaceae collected from Hunakosiyama, Harima and Koetuyama, Awa in Japan by $\mathrm{Mr}$. K. Utiumi and Mr. E. Akamatu who very kindly passed it to me for investigation. Formalin-acetic-alcohol fluid was used for fixation. The sections were cut at a thickness 10-15 microns and stained with Heidenhain's iron-alum-haematoxylin.

Ovule and embryo sac. The ovary is, as common in other Scrophulariaceae, bilocular and has axial placentation with 6-8 anatropous ovules (Fig. 1 and 2 ). The mature ovule is hemispheric and has a single integument being made up of 13-14 layers of cells on the outside. A hypodermal archesporial cell divides giving rise to a linear tetrad of four megaspores. The chalazal megaspore functions and gives rise to the embryo sac (Fig. 3). In this stage the nucellar cells become flattened and are completely destroyed when the embryo sac matures. The innermost layer of the integument constructs the endothelium with the quadrilateral cells containing

* Botanical Institute, Faculty of Szience, University of Tokyo, Hongo, Tokyo. 東京大学理学部 植物学教室

** This study was defrayed by the Scientific Research Fund of Ministry of Education. 
prominent nucleus and dense cytoplasm. The endothelium invests the embryo sac partially, the antipodal and the micropylar ends are free (Fig. 4). In the early stage of the embryo sac formation, the integumental cells of chalazal part contain large nuclei and dense cytoplasm, and become nutritive tissue (Fig. 4.). After the fertilization, these cells are lost their contents, and their wall thickens, thus the hypostatical tissue is formed (Fig. 5). The mature embryo sac is spathulate in shape and is formed of two portions being the broad globular micropylar and the elongated chalazal ones. Three antipodal cells lie side by side immediately disintegrate after fertilization.

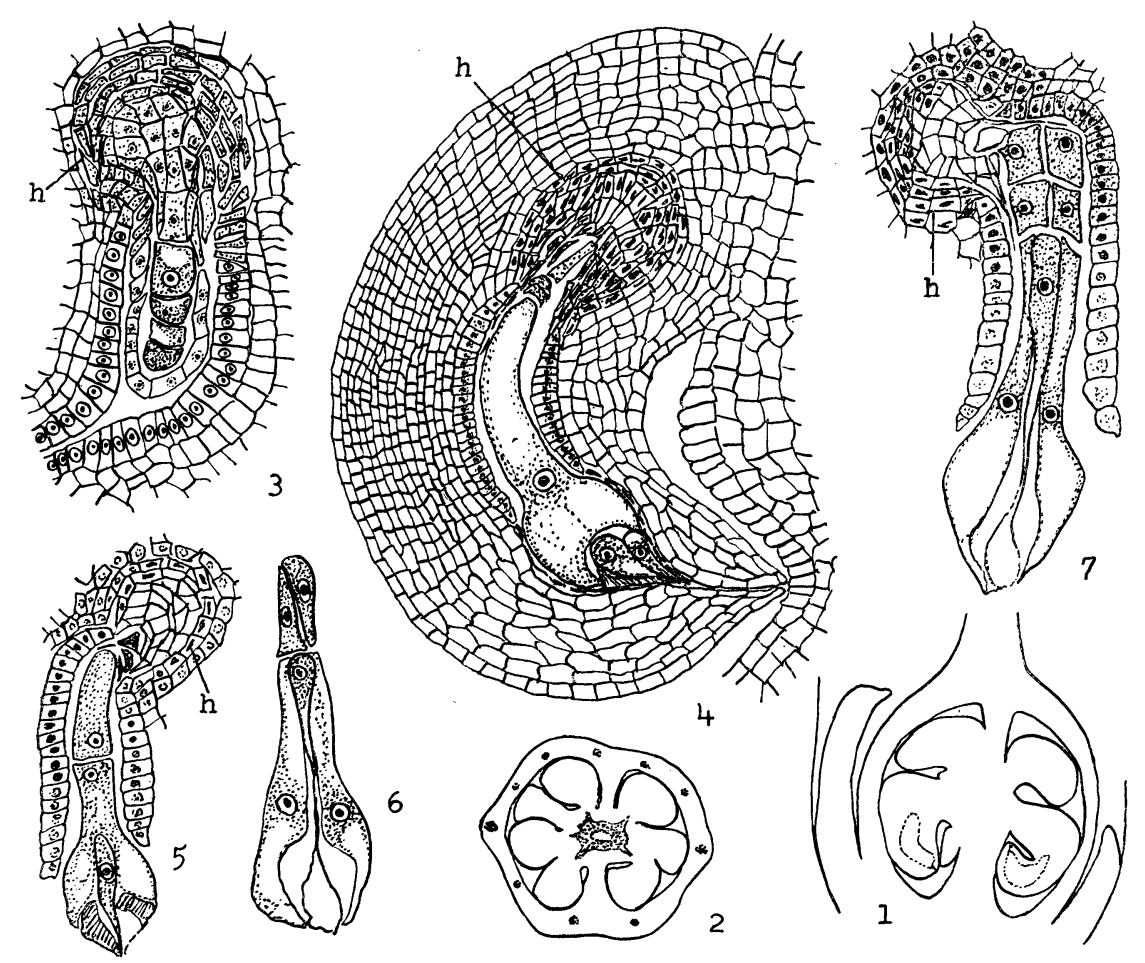

Fig. 1. Longitudinal section of the ovary, $\times 50$. Fig. 2. Transverse section of the ovary, $\times 50$. Fig. 3 . Tetrad showing the upper three degenerated megaspores. $\times 500$ Fig. 4. Ovule showing the mature embryo sac. $\times 400$. Fig. 5. Two celled endosperm. $\times 400$. Fig. 6 . Four celled endosperm. $\times 400$. Fig. 7. Six celled endosperm. $\times 400$.

Formation of the endosperm. The endosperm is of the cellular type. The embryo sac enlarges after fertilization. The first division of the primary endosperm nucleus takes place with a transverse wall to form a micropylar and a chalazal chambers (Fig. 5). Then longitudinal divisions in both cells result four-celled chambers (Fig. 6). These two micropylar chambers do not divide further and act as the haustorium, and two chalazal ones undergo further transverse divisions resulting two tiers of two cells each (Fig. 7). These four cells undergo further con- 
tinuous transverse and longitudinal divisions to produce the endosperm proper. With the progress of the endosperm formation, the endosperm and the embryo become bent toward the dorsal side to penetrate into the integument (Fig. 8). In the second cell generation of the embryo, the cells of the dorsal side of the endosperm containing prominent nucleus and dense cytoplasm, rapidly divide forming the globular mass of cells, on the other hand, the cells of the micropylar and the chalazal parts of the endosperm become large and highly vacuolate (Fig. 9.). In the third and the fourth cell generations of the embryo, the doras1 globular mass of the endosperm gradually expands on the lateral side and forms a handle-shaped mass of cells containing dense cytoplasm. At the same time, some cells of the ventral side of the endosperm become swallen and highly vacuolate, and then are rapidly elongate and

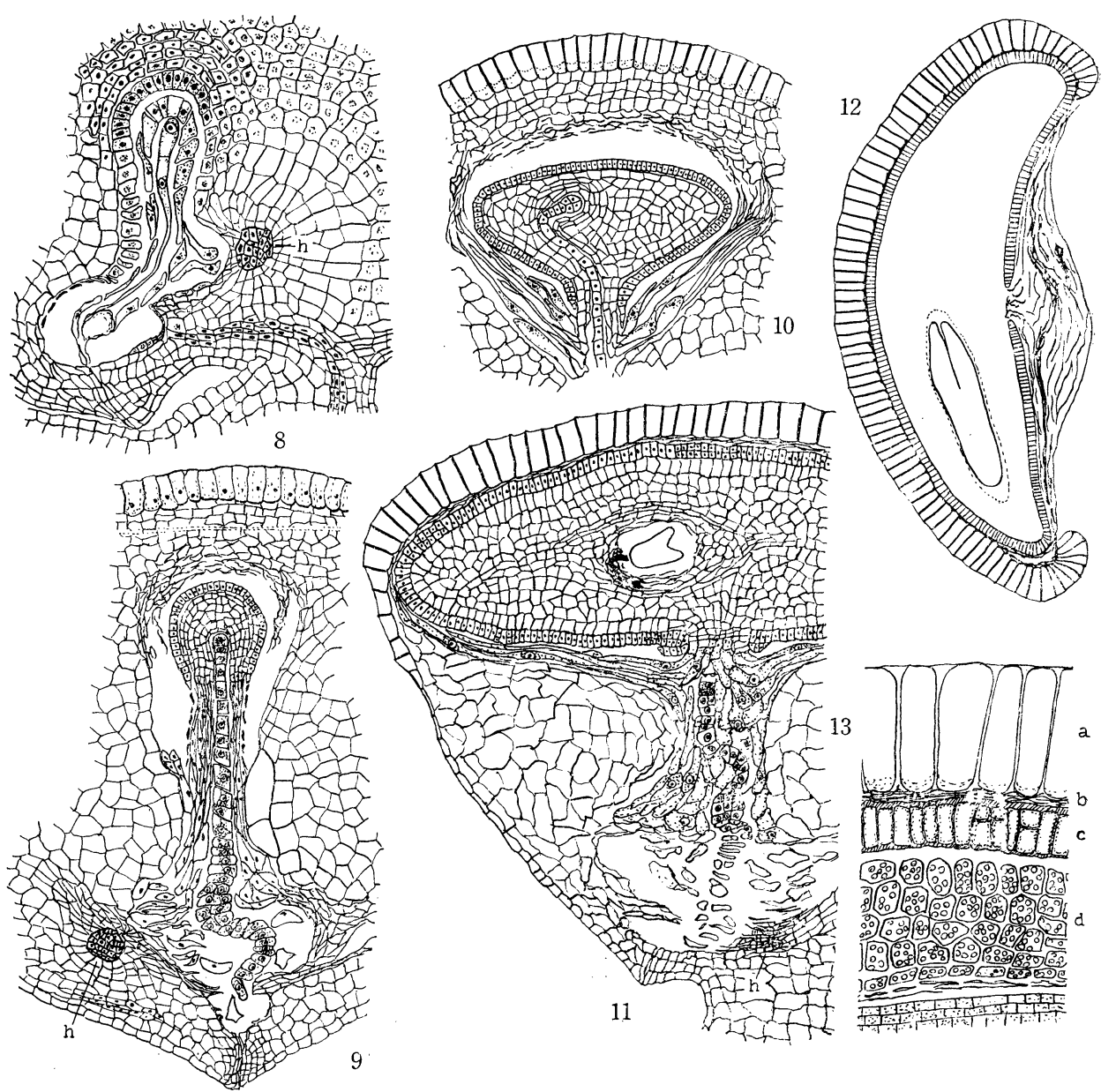

Figs. 8-11. Formation of the seed. Fig. 8, $\times 140$. Figs. 9-10, $\times 80$. Fig. $11, \times 60$. Fig. 12. Mature seed. $\times 35$. Fig. 13. A portion of the mature seed. $\times 160$ h-hypostatical region. a-epidermal cells. b-integumental cells. c-endothelial cells. dendospermal cells filled with many starch grains. e-a portion of the embryo. 
spread abroad along the endothelium (Fig. 10). These cells act as the haustorium. Finally, the mature endosperm becomes a disk-shaped mass of cells in which the cells arround the embryo are gradually broken down. The outer four or five layers of endospermal cells persist until the seed matures and are filled with starch (Fig. 13.).

Development of the endothelium. At the early stage of the endosperm formation, the endothelial cells of the ventral side gradually lose their contents (Fig. 7) and disintegrate completely at the stage of two celled embryo (Fig. 8). While, on the other hand, the dorsal endothelial cells containing dense cytoplasm divide actively and penetrate into the integument (Fig. 7). These cells of the micropylar and the chalazal parts gradually disintegrate. The middle cells divide anticlinally to produce a globular body invested the endosperm (Fig. 9). When the seed matures, the endothelium is made up one or rarely two layers of cells which are rectangular and stained darkbrown, and becomes the cutinized seed coat (Fig. 12).

Formation of the embryo. After the fertilization, the zygote rapidly elongates and moves into the endosperm (Fig. 7). The first division is transverse and gives

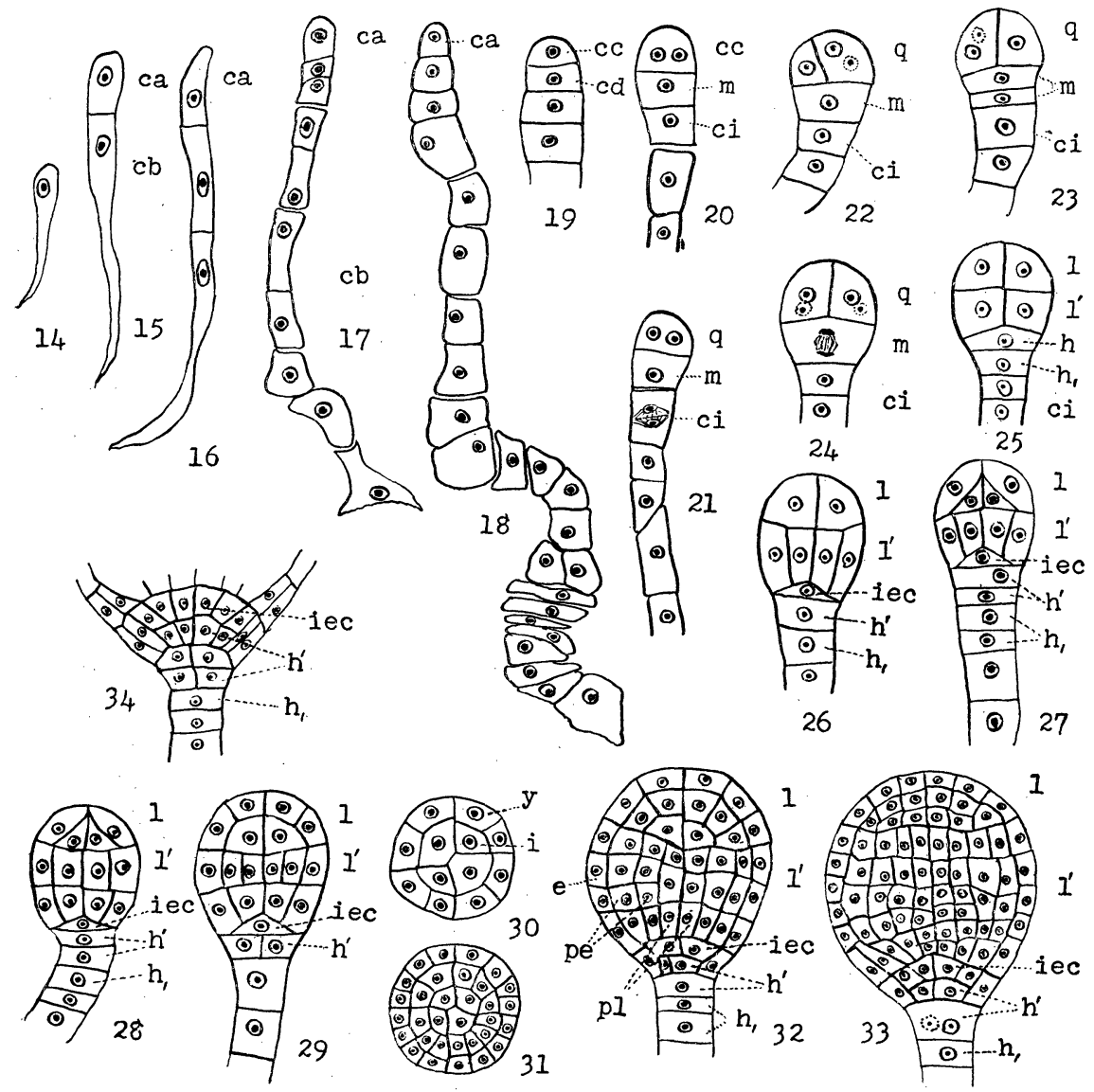

Figs. 14-34. Formation of the embryo. Figs. 14-18, $\times 30$. Figs. 19-34, $\times 460$. 
rise to an apical cell (ca) and a basal cell (cb) (Fig. 15). The basal cell (cb) repeats. many continuous transverse divisions to produce an elongated filament which is composed of 40-50 cells (Fig. 9 and 18). These cells become swollen and highly vacuolate, and act as the suspensor haustorium. A terminal cell (ca) divides transversely into two superposed cells (cc) and (cd) (Fig. 19). The element (cd) divides transversely into two superposed cells (m) and (ci) (Fig. 20). The upper cell (m) differentiates as the hypophysial cell, and the lower cell (ci) accepts few transverse divisions and contributes to the construction of the upper part of the suspensor. At the third cell generation of the embryo, the elements ( $m$ ) divides transversely to produce two superposed cells, (h) and (h,) (Fig. 25). After the fourth cell generation, the cell (h) divides transversely to produce two superposed cells (iec) and $\left(h^{\prime}\right)$ (Fig. 26). The element (iec) which is lenticular in shape and presses into the upper spheric part of the embryo, by two succeeded longitudinal divisions becomes four cells and represents the initials of the root cortex. The element $\left(h^{\prime}\right)$ which by two succeeded longitudinal divisions gives rise four cells and by the next transverse divisions eight cells, represents the iritials of the uppermost cell of the root cap (Fig. 34).

The uppermost ce11 (cc) divides longitudinally into two juxtaposed cells, whereupon each daughter cell undergoes a longitudinal division perpendicularly to the previous plane of division and produces four cells (Fig. 24). Transverse divisions in each of these four cells result two tiers of four cells each (1) and (1') (Fig. 25). Four cells of the upper tier (1) which give rise to the cotyledonary portion eventually, divide by tangential wall, thus formed outer daughter cells repeatedly divide anticlinally and give rise to the epidermal initials, the inner daughter cells then divides by generally vertical walls to separate the mother cells of the cotyledorary initials exteriorly and the elements which enter into the construction of the stem apex interiorly. Four cells of the lower tier $\left(1^{\prime}\right)$ which give rise to the hypoctyledonary region, divide by vertical walls to produce eight cells (Fig. 27). Transverse divisions in each of these eight cells result two tiers of eight cells each (Fig. 28). Thus formed outer daughter cells repeatedly divide anticlinally and give rise to the epidermal initials, the inner daughter cells by the continuous pericliral and anticlinal divisions from the plerome initials (p1) and the periblem ones (pe) (Fig. 32). In transverse sections through the regions (1) and (1') (Fig. 30 and 31), four cells of each tiers are divide by a periclinal wall producing the outer more or less rectangular and foursided cells (y) and the inner more or less triargular and three-sided ones (i). The cells of the outer element (y) repeatedly divide anticlinally and give rise to the epidermal initials. In the lower tier $\left(1^{\prime}\right)$, the cells of the inrer element (i) repeat to divide periclinally ard produce the outer sided cells (pe) representirg the periblem initials and the inner three sided ones representing the plerome initials (p1) (Fig. 31).

Formation of the seed coat. Very early in the endosperm formation, many integumental cell layers are visible between the endothelium and the epidermis. 
At the stage when the endospermal cells penetrate into the integument, the inner integumental cells are gradually broken down and the epidermal cells of the integument enlarge greatly. When the endosperm is fully developed, the inner integumental cells are completely disintegrate and remain in thin membrane. The epi* dermal cells of the integument elongate and become the mucilaginous hairs (Fig. 12 and 13).

Discussion. The processes of the endosperm and the embryo formations of Ellisiophyllum pinnatum remarkably differ from those of other members of Scrophulariaceae. In the former, the endosperm penetrates into the dorsal side of the integument, and the original part of the embryo sac is emptied its contents. Many lower endospermal cells elongate rapidly along the endothelium forming the filamentous cells which act as the haustorium. In the other members of Scrophulariaceae, the endosperm develops in the original part of the embryo sac, and the micropylar and the chalazal haustoria being constructed of one, two or four cells, are separately formed at either end of the endosperm.

Formation of the embryo of Ellisiophyllim pinnatum is essentially the same as those of other members of Scrophulariaceae, but some differences are found each others in the following respects. In Ellisiophyllum pinnatum, the terminal cell (ca) is segemented transversely to give rise two cells, (cc) and (cd). The uppemost cell (cc) is divided longitudinally into two juxtaposed cells and produces the stem. tip, cotyledonary and hypocotyledonary portions. The lower cell (cd) produces the initials of the root cortex, root cap and the upper part of the suspensor. The basal cell $(\mathrm{cb})$ of the two celled proembryo reparts many transverse divisions to give rise the many-celled suspensor. These cells of the suspensor become swollen and act as the haustorium. These characters above mentioned are not found in other Scrophulariaceae, but are the same as those of Hypericum perforatum (Souèges 1925), Androsaemum officinale (Souèges 1936), and Actinidia chinensis (Souèges 1943).

In the other members of Scrophulariaceae, the terminal cell (ca) of two celled proembryo divides by a longitudinal wall giving rise two juxtaposed cells, and produces the stem tip, cotyledonary and hypocotyledonary portions. The lower cell (cb) produces the initials of the root cortex, root cap, and suspensor. This suspensor is slender and filamentous, and degenerates in early stages of the embryo development. The suspensor haustorium has never been found in Scrophulariaceae except an instance of Striga lutea reported by M. R. Mitchell (1915). However, B. Tiagi (1956) reported that "This observation. of Mitchell is probably incorrect. Her figure 23 which represents this shows that she has mistaken the micropyral haustorial cell for a cell of the suspensor."

M. Honda (1930 and 1939) established an independent family Ellisiophyllaceae, or a subfamily Ellisiophylloideae in Scrophulariaceae based on this genus. The structure of the flower and the ovary of Ellisiophyllum is common to that of other members of Scrophulariaceae. But the above mentioned facts indicate that this 
genus is very peculiar having certain special features of its own in embryology and holds a unique position in Scrophulariaceae.

\section{Literature cited}

Honda M., Syst. Plant. Japonicarum ed. 1, 372 (1930). ibid. ed. 2, 278 (1939). Mitchell

M. R., Bot. Gaz. 59: 124-135 (1915). Souèges R., Compt. Rend. Acad. Sci. 180 : 949-951 (1925). ibid., 202: 679-681 (1936). ibid. 217; 430-432 (1943). Tiagi B., Bull. Torrey Bot. Club $83: 154-170$ (1956). Yamazaki T., Journ. Jap. Bot. $27: 61$ (1952).

\section{Some Dynamic Properties of the Protoplasmic Streaming in Chara* \\ by Toshio HAYASHi* \\ 林＼cjkstart俊郎**：シャジクモの細胞に抬ける原形質流動の動的锥察}

Received February 6, 1957

Many works have been done recently on the protoplasmic streaming in the myxomycete plasmodium regarding its motive force and energy source (Kamiya 1940-1956 and Ohta 1952). The dynamic properties of the protoplasmic streaming is so far best investigated in this material. The plasmodium of the myxomycete is, however, quite different from general plant cells both in appearance and behaviour. The rate of streaming of protoplasm in myxomycete is not only enormously high but the direction changes alternately according to a rhythmic pattern. Having no cell wall, the streaming of protoplasm in the plasmodium necessarily involves a change in shape.

On the other hand, our knowledge is still meager in respect to the dynamics of the rotational streaming. This paper deals with the effect of gravity and centrifugal acceleration on the internodal cell of Chara, one of the representative material showing rotational streaming, with the hope that it may throw some light on the dynamic character of the rotational streaming.

\section{Material and methods}

Internodal cells of Chara Braunii were used for material. The healthy internodal cells near the apical end, which are 0.5-3.0 centimeters long, are freed from the neighbouring cells for experiment.

\footnotetext{
* This work has been supported by a Grant in aid for Developmental Scientific Research of the Ministry of Education.

** Biological Institute, College of General Education, University of Tokyo. 東京大学教養学部生 物学教堂
} 